\title{
Autoimmune thyroid disease and thyroid function test fluctuations in patients with resistance to thyroid hormone
}

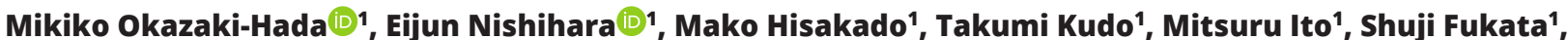
Mitsushige Nishikawa', Takashi Akamizu' ${ }^{1}$ and Akira Miyauchi

${ }^{1}$ Department of Internal Medicine and ${ }^{2}$ Department of Surgery, Center for Excellence in Thyroid Care, Kuma Hospital, Chuo-ku, Kobe, Japan

Correspondence should be addressed to E Nishihara

Email

nishihara@kuma-h.or.jp

\begin{abstract}
Objective: Resistance to thyroid hormone beta $(\mathrm{RTH} \beta)$ is an inherited syndrome caused by mutations in the thyroid hormone receptor $\beta$ (THRB) gene. Patients with RTH $\beta$ typically have elevated thyroid hormone levels with nonsuppressed serum thyroid-stimulating hormone (TSH). We aimed to elucidate the clinical, laboratory, and imaging findings of RTH $\beta$ patients and further to explore their association with THRB gene mutations.

Design and methods: We retrospectively reviewed the clinical charts and compared the clinical findings of 68 RTH $\beta$ patients ( 45 probands and 23 relatives) and 30 unaffected relatives in Kuma Hospital.

Results: Genetic testing revealed 35 heterozygous THRB gene mutations. Among all RTH $\beta$ patients, autoimmune thyroid disease (AITD) was detected in $42.1 \%$ of men and $40.9 \%$ of women, showing that the prevalence of AITD in affected males was significantly higher than in unaffected relatives $(P=0.019)$. During the follow-up of 44 patients, 13 patients (29.5\%; 8 (42.1\%) with AITD and 5 (20\%) without AITD) temporarily showed thyroid function test results inconsistent with RTH $\beta$. Two patients with the R383H mutation, which has little dominant-negative effect, temporarily showed normal thyroid hormone and TSH levels without AITD.

Conclusions: The frequency of AITD in male RTH $\beta$ patients was significantly higher compared to unaffected relatives. More than $20 \%$ of RTH $\beta$ patients temporarily showed laboratory findings atypical of RTH $\beta$ during their follow-up, and patients with AITD and specific THRB mutations were prone to display such findings. Therefore, genetic testing should be performed even for patients with fluctuations in thyroid function test results to avoid misdiagnosis and inappropriate treatment.

\section{Introduction}

Resistance to thyroid hormone beta (RTH $\beta$ ) is an inherited condition, which was first described by Refetoff et al. (1). Mutations in the thyroid hormone receptor $\beta$ (THRB) gene have been identified in the majority of patients with RTH $\beta$, with more than 4000 patients belonging to over 600 families (2). In general, patients with RTH $\beta$ are identified using discrepant thyroid function test and elevated serum levels of free T4 (FT4) and free T3 (FT3) with non-suppressed thyroid-stimulating hormone (TSH). Most studies involving a large number of patients with RTH $\beta$ originate from North America and Europe $(3,4,5)$. However, no studies involving a large series of patients with RTH $\beta$ have been conducted in Asian countries including Japan.

Barkoff et al. reported that $23.3 \%$ of patients with RTH $\beta$ had a comorbid autoimmune thyroid disease (AITD). They described that individuals with RTH $\beta$ have an increased likelihood of developing AITD (6). Vela et al. (4) and Rivolta et al. (7) reported that thyroid autoantibodies were Printed in Great Britain

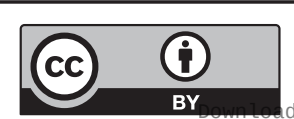

This work is licensed under a Creative Commons Attribution 4.0 International License. 
found in 25 and $22.2 \%$ of patients with RTH $\beta$ in Spain and South America, respectively. However, these studies did not investigate the increase in thyroid autoantibodies in patients with RTH $\beta$ in comparison to a control. A study of the general Japanese population reported that thyroid autoantibodies were detected in $23.4 \%$ of women and $14.8 \%$ of men with non-palpable goiters (8). No study has reported the prevalence of AITD among Japanese patients with RTH $\beta$.

The main purpose of this study was to evaluate the clinical, laboratory, and imaging findings of patients with RTH $\beta$ in Japan, an iodine-sufficient or even excess area, and further to explore their association with THRB gene mutations.

\section{Patients and methods}

\section{Participants}

A total of 174 patients with probands suspected of having RTH $\beta$ consulted Kuma Hospital and underwent THRB sequencing between July 2003 and May 2020. Among them, 45 patients were confirmed to have THRB mutations. Relatives of these patients underwent gene analysis to determine if any of them also had THRB mutations. THRB gene sequencing confirmed mutations in 23 and normal sequences (WT) in 30 relatives. Overall, the study included 98 individuals divided into three groups: 45 probands, 23 affected relatives, and 30 unaffected relatives. All patients with RTH $\beta$ (68 patients) were genetically confirmed as having THRB gene mutations. All participants provided informed consent to participate in this study. The study protocol was approved by the Ethics Committee of Kuma Hospital (No. 20200709-1) and was conducted in accordance with the principles of the Declaration of Helsinki.

\section{Clinical characteristics and symptoms}

The clinical characteristics of the patients were obtained from the medical records. Sixty-seven patients with RTH $\beta$ were asked to answer a questionnaire and completed to describe their subjective symptoms. To assess concurrent atrial fibrillation, we evaluated the medical history and

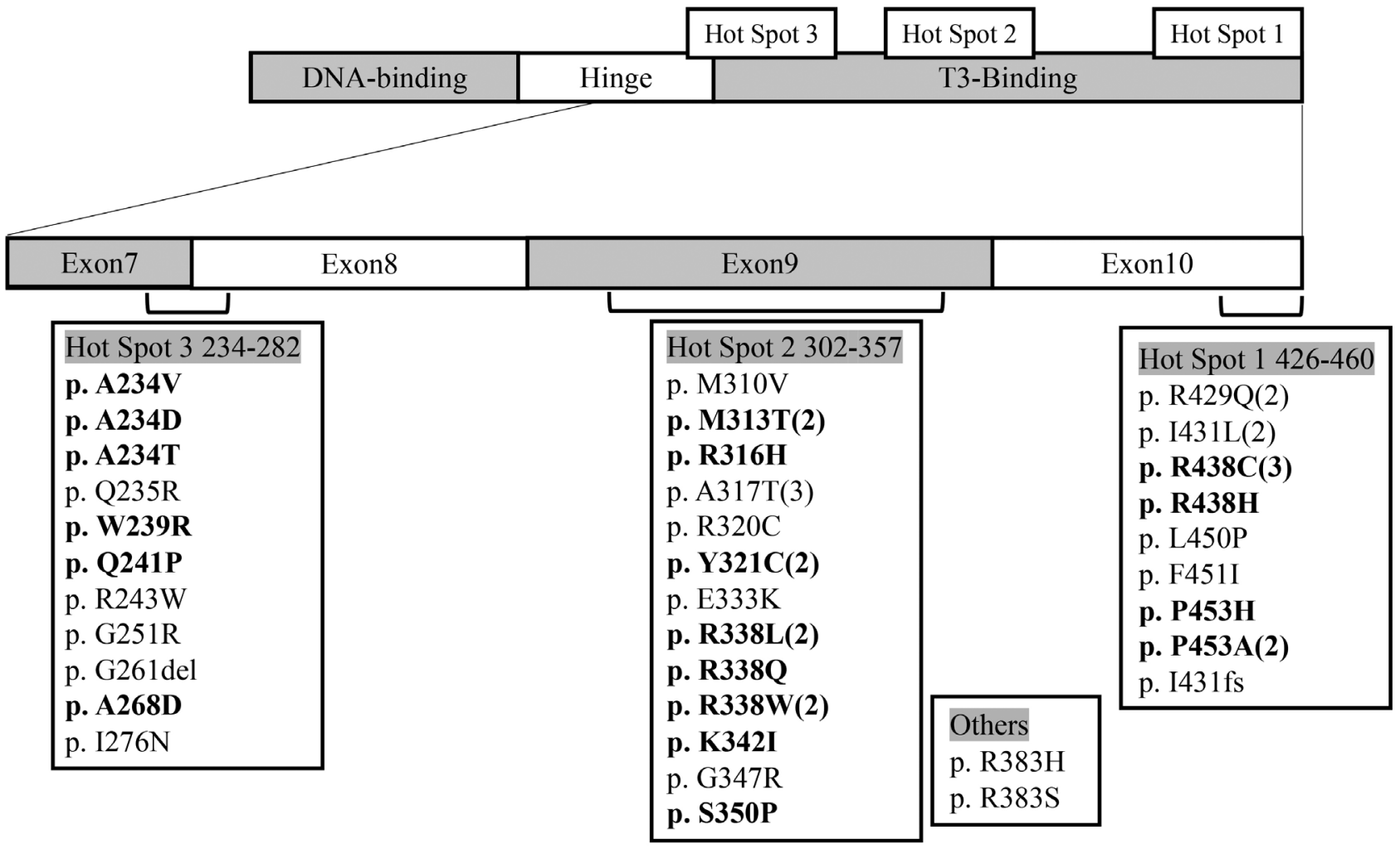

Figure 1

Mutations of THRB in our study. The number of different families showing the same mutation is shown in brackets. Genetic variants that include one or more members with AITD are shown in bold. 
Table 1 Types and characteristics of THRB mutations. Total numbers are indicated in parentheses.

\begin{tabular}{|c|c|c|c|}
\hline Exon & TSHB mutation & $\begin{array}{c}\text { Number of } \\
\text { family }\end{array}$ & Male/female \\
\hline 7 & A234V & 1 & $1 / 1$ \\
\hline 7 & A234D & 1 & $2 / 2$ \\
\hline 7 & A234T & 1 & $1 / 1$ \\
\hline 7 & Q235R & 1 & $1 / 0$ \\
\hline 7 & W239R & 1 & $0 / 1$ \\
\hline 7 & Q241P & 1 & $1 / 1$ \\
\hline 7 & R243W & 1 & $0 / 2$ \\
\hline 8 & G251R & 1 & $0 / 1$ \\
\hline 8 & G261del & 1 & $0 / 1$ \\
\hline 8 & A268D & 1 & $0 / 1$ \\
\hline 8 & $1276 \mathrm{~N}$ & 1 & $0 / 1$ \\
\hline 9 & M310V & 1 & $0 / 1$ \\
\hline 9 & М313Т & 2 & $2 / 0$ \\
\hline 9 & R316H & 1 & $0 / 1$ \\
\hline 9 & A317T & 3 & $0 / 3$ \\
\hline 9 & R320C & 1 & $0 / 1$ \\
\hline 9 & Y321C & 2 & $1 / 2$ \\
\hline 9 & E333K & 1 & $0 / 1$ \\
\hline 9 & R338L & 2 & $1 / 4$ \\
\hline 9 & R338Q & 1 & $1 / 0$ \\
\hline 9 & R338W & 2 & $0 / 2$ \\
\hline 9 & K342I & 1 & $2 / 3$ \\
\hline 9 & G347R & 1 & $1 / 0$ \\
\hline 9 & S350P & 1 & $1 / 0$ \\
\hline 10 & $\mathrm{R} 383 \mathrm{H}$ & 1 & $2 / 2$ \\
\hline 10 & R383S & 1 & $0 / 1$ \\
\hline 10 & R429Q & 2 & $0 / 2$ \\
\hline 10 & |431L & 2 & $1 / 1$ \\
\hline 10 & $\mathrm{R} 438 \mathrm{C}$ & 3 & $1 / 2$ \\
\hline 10 & $\mathrm{R} 438 \mathrm{H}$ & 1 & $0 / 1$ \\
\hline 10 & L450P & 1 & $0 / 1$ \\
\hline 10 & F451I & 1 & $0 / 1$ \\
\hline 10 & $\mathrm{P} 453 \mathrm{H}$ & 1 & $1 / 3$ \\
\hline 10 & P453A & 2 & $0 / 2$ \\
\hline \multirow[t]{2}{*}{10} & $1431 \mathrm{fs}$ & 1 & $1 / 1$ \\
\hline & & & $(21 / 47)$ \\
\hline
\end{tabular}

\begin{tabular}{c}
\hline AITD (positive/total examined \\
members) \\
\hline $1 / 2$ \\
$2 / 4$ \\
$1 / 2$ \\
$0 / 1$ \\
$1 / 1$ \\
$1 / 2$ \\
$0 / 2$ \\
$0 / 1$ \\
$0 / 1$ \\
$1 / 1$ \\
$0 / 1$ \\
$0 / 1$ \\
$2 / 2$ \\
$1 / 1$ \\
$0 / 2$ \\
$0 / 1$ \\
$1 / 2$ \\
$0 / 1$ \\
$3 / 5$ \\
$1 / 1$ \\
$1 / 2$ \\
$5 / 5$ \\
\\
$0 / 1$ \\
$1 / 1$ \\
$0 / 4$ \\
$0 / 1$ \\
$0 / 2$ \\
$0 / 1$ \\
$1 / 3$ \\
$1 / 1$ \\
$0 / 1$ \\
$0 / 1$ \\
$1 / 3$ \\
$1 / 2$ \\
$0 / 1$ \\
$(26 / 63)$ \\
\\
\end{tabular}

Data inconsistent with RTH $\beta$

Overt hypothyroidism (1)

NA

Subclinical thyrotoxicosis (1)

NA

$-$

Overt hypothyroidism (1)

Subclinical thyrotoxicosis (1)

NA

NA

NA

$-$

NA

Overt hypothyroidism (2)

Overt thyrotoxicosis (2)

Euthyroidism (2)

Subclinical thyrotoxicosis (1)

$-$

Overt hypothyroidism (1)

-

$-$

NA

Subclinical thyrotoxicosis (1) checked pulse in all 68 patients at the initial examination. Further ECG examination was performed for 32 patients.

\section{Laboratory and ultrasound tests}

Laboratory results of 63 patients with RTH $\beta$ and 25 unaffected relatives were available, while 5 patients with RTH $\beta$ (A317T, Y321C, I431L, I431fs, and P453H) and 5 unaffected relatives were excluded because they were under the age of 15 (Supplementary Fig. 1, see section on supplementary materials given at the end of this article). Between July 2003 and December 2018, TSH, FT4, and FT3 levels were measured using chemiluminescent immunoassays (Abbott); reference ranges, TSH (0.3-4.9 $\mu \mathrm{IU} / \mathrm{mL})$, FT4 (0.7-1.6 ng/dL), and FT3 (1.7-3.7 pg/
mL). After January 2019, electrochemiluminescence immunoassays (Roche Diagnostics); reference ranges, TSH (0.5-5.0 $\mu \mathrm{IU} / \mathrm{mL})$, FT4 (0.9-1.7 ng/dL), and FT3 (2.3-4.0 $\mathrm{pg} / \mathrm{mL}$ ) were used.

Basal thyroid function tests were performed at least 1 month after patients who were misdiagnosed with Graves' disease discontinued anti-thyroid drugs. All participants except one unaffected relative were checked for thyroid autoantibodies ( Supplementary Fig. 1) using methods described as follows. Before March 2008, four patients and one unaffected relative were evaluated by hemagglutination assay kits (microsomal hemagglutinin antibody (MCHA): Microsome test and thyroglobulin hemagglutinin antibody (TGHA): Thyroid test, Fuji Rebio Inc., Tokyo, Japan) and one patient was evaluated 
Table 2 Baseline characteristics of RTH $\beta$ patients (45 probands). Data are presented as median (interquartile range, IQR).

\begin{tabular}{lc}
\hline Parameter & \\
\cline { 1 - 1 } Male/female & $9 / 36$ \\
Age at diagnosis among & $36.0(25.0-49.5)$ \\
probands (years) & \\
$0-10$ & $6.7 \%$ \\
$11-20$ & $8.9 \%$ \\
$21-30$ & $22.2 \%$ \\
$31-40$ & $20.0 \%$ \\
$41-50$ & $22.2 \%$ \\
$51-60$ & $8.9 \%$ \\
$>61$ & $11.1 \%$ \\
Reasons for visit & \\
Goiter & $22.2 \%$ \\
Palpitation & $20.0 \%$ \\
Abnormal thyroid function* & $57.8 \%$ \\
\hline
\end{tabular}

*Abnormal thyroid function found during the examination of symptoms that are not related to RTH, or during the health checkup.

using RIA for thyroid peroxidase antibody (TPOAb) and thyroglobulin antibody (TgAb) (Cosmic Co, Hiroshima, Japan). After April 2008, TPOAb and TgAb were measured for 58 patients with RTH $\beta$ and 23 unaffected relatives using an electrochemiluminescence immunoassay (Roche Diagnostics). For MCHA and TGHA, titers of 1:100 or more were regarded as positive. TPOAb $\geq 0.3 \mathrm{IU} / \mathrm{mL}$ and $\mathrm{TgAb}$ $\geq 0.3 \mathrm{IU} / \mathrm{mL}$ by RIA, and TPOAb $\geq 16.0 \mathrm{IU} / \mathrm{mL}$ and $\mathrm{TgAb}$ $\geq 28.0 \mathrm{IU} / \mathrm{mL}$ by electrochemiluminescence immunoassay were determined to be positive.

Data based on ultrasound examination were available in 56 patients with RTH $\beta$ and in 21 unaffected relatives who were at least 15 years old (Supplementary Fig. 1). Thyroid volume was measured by ultrasound and was calculated using the equation as described previously (9). For evaluation of the malignant potential, we used the ultrasound classification system based on the shape and echo features of thyroid nodules as reported previously (10, 11) and measured the maximum diameter of nodule sizes.

The patients with AITD have satisfied the diagnostic criteria, that is, positive values for TPOAb and/or TgAb, with either hypoechoic and/or inhomogeneous pattern, in thyroid ultrasonography or lymphocytic infiltration in the thyroid gland with cytological examination.

\section{Gene analysis}

Genomic DNA was extracted from peripheral leukocytes using the QIAamp DNA Blood Mini Kit (Qiagen). Exons 7-10 of the THRB1 gene were amplified by PCR using a High Fidelity PCR Master (Roche Diagnostics). Conditions were as follows: initial denaturation for $10 \mathrm{~min}\left(94^{\circ} \mathrm{C}\right)$, followed
Table 3 Baseline characteristics of 68 RTH $\beta$ patients (total; probands and relatives).

\begin{tabular}{lll}
\hline Parameter & & \\
\hline Male/female & & $21 / 47$ \\
Probands/relatives & $45 / 23$ \\
Frequency of subjective symptoms & \\
$\quad$ Palpitation & $38.8 \%$ \\
$\quad$ Goiter & $34.3 \%$ \\
$\quad$ Sweating & $23.9 \%$ \\
Hand tremor & $13.4 \%$ \\
Anxiety & $14.9 \%$ \\
$\quad$ Weight loss & $11.9 \%$ \\
Misdiagnosed as Graves' disease & $13.2 \%$ \\
\hline
\end{tabular}

by 35 cycles of denaturation for $1 \mathrm{~min}\left(94^{\circ} \mathrm{C}\right)$; annealing for $1 \mathrm{~min}\left(55^{\circ} \mathrm{C}\right)$; and elongation for $1 \mathrm{~min}\left(72^{\circ} \mathrm{C}\right)$, with a final elongation step at $72^{\circ} \mathrm{C}$ for $3 \mathrm{~min}$. The four sets of forward and reverse primers were as follows: exon 7, 5'-CAG TAA GCC ATC TGT GCA TC-3' and 5'-GGC AAT AAC ACC AGT ATC CC-3'; exon 8, 5'-ACT GTA CAG GAT ATC AGT TC-3' and 5'-AGT ATT CCT GGA AAC TGA TG-3'; exon 9, 5'- TCA CAG AAG GTT ATT CCT ATT-3' and 5'-ACT CAA GTG ATT GGA ATT AG-3'; and exon 10 ,5'-CTA AGA GGG AAG ACC CTA GA-3' and 5'-TTT CCC TCC CAA ATA ATC CC-3'. Direct sequencing of PCR products was performed using the Bigdye Terminator v1.1 Cycle Sequencing Kit (Applied Biosystems) and an automatic ABI 3130 sequencer (Applied Biosystems).

\section{Statistical analysis}

All analyses were performed using StatFlex version 6.0 software (Artech Co., Osaka, Japan). Values are presented as medians (interquartile range (IQR)). Categorical values were compared using a $\chi^{2}$ test, and other values were analyzed using the Mann-Whitney $U$-test. Statistical significance was set at $P<0.05$.

\section{Results}

Genetic testing revealed 35 heterozygous THRB gene mutations. All except two (p.R383H and p.R383S) were localized in three hot spot regions of the THRB described previously (2). They included 33 missense, 1 deletion, and 1 insertion mutation. The most prevalent mutations in this study were A317T and R438C, each harbored by three unrelated families (Fig. 1 and Table 1).

The clinical characteristics of the 45 probands with RTH $\beta$ are shown in Table 2 . The median age at diagnosis among probands was 36.0 (25.0-49.5) years, and over 
$40 \%$ of the patients were found to have RTH $\beta$ for the first time at age, 40 years or older. Of the probands, $57.8 \%$ initially consulted our hospital for further investigation of RTH $\beta$ due to abnormalities in their thyroid function test results. Collating the data of all patients with RTH $\beta$ (Table 3), the questionnaire showed that palpitations and goiter were the main chief complaints and were present in 38.8 and $34.3 \%$ of the patients, respectively. Medical history and ECGs showed that 7.4\% (5/68) of the patients had concurrent atrial fibrillation. Importantly, $13.2 \%$ (9/68) of the patients were misdiagnosed with Graves' disease at initial evaluation; consequently, nine patients were prescribed anti-thyroid drugs (six with thiamazole and two with propylthiouracil) and one patient who had undergone subtotal thyroidectomy at a hospital elsewhere was also prescribed thiamazole after recurrence of thyroid enlargement to $62 \mathrm{~mL}$.

FT4 and FT3 levels were significantly higher in patients with RTH $\beta$ compared to unaffected relatives (Table 4). Among RTH $\beta$ patients, $42.1 \%$ of male patients and $40.9 \%$ of female patients had positive TPOAb and/or TgAb. The frequency of thyroid autoantibodies in male RTH $\beta$ patients was significantly higher compared to unaffected male relatives $(P=0.019)$. We also performed thyroid ultrasound and/or fine-needle aspirations for cytology in all RTH $\beta$ patients $(n=26)$ and all unaffected relatives $(n=7)$ who had positive thyroid autoantibodies. Hypoechoic and/or inhomogeneous pattern in ultrasonography was detected in all subjects but one. The remaining one had lymphocytic infiltration in cytological specimens in the thyroid. All 33 subjects showing positive thyroid autoantibodies had these typical findings of chronic thyroiditis defined as AITD. There were no significant differences in TSH levels (median (IQR), 2.8 (1.7-3.9) vs $2.0(1.4-2.7) \mu \mathrm{IU} / \mathrm{mL}$, $P=0.052)$ or ages $(40.0(27.3-59.3)$ vs $36.0(28.5-48.5)$ years old, $P=0.46$ ) between RTH $\beta$ patients with and without AITD. The median thyroid volume among RTH $\beta$ patients was significantly larger compared to unaffected relatives ( $P=0.0033$ in male and 0.0072 in female, respectively). While $34.3 \%$ presented with a subjective symptom of goiter (Table 3), the ultrasound data showed that twice as many patients $(73.2 \%)$ had goiter with a thyroid volume $\geq 20 \mathrm{~mL}$. While nodules with solid components were detected in $42.9 \%$ of the RTH $\beta$ patients, malignancy was not suspected in any of them upon ultrasound evaluation and fine-needle aspiration.

We evaluated the sequential thyroid function in 44 RTH $\beta$ patients who consulted our hospital more than twice (Supplementary Fig. 1). Among them, 13 patients (29.5\%), 8 with AITD and 5 without AITD, temporarily showed data

Table 4 Laboratory and ultrasound data (RTH $\beta$ vs unaffected relatives, data age $>15$ years old). Data are presented as median (IQR). AITD pattern: hypoechoic and/or inhomogeneous pattern.

\begin{tabular}{|c|c|c|c|}
\hline & $\mathbf{R T H} \beta(n=63)$ & unaffected relatives $(n=25)$ & $P$ value \\
\hline Male/female & $19 / 44$ & $6 / 19$ & 0.56 \\
\hline TSH ( $\mu \mathrm{IU} / \mathrm{mL})$ & $2.2(1.5-3.2)$ & $1.9(1.0-2.6)$ & 0.15 \\
\hline $\mathrm{FT} 4$ (ng/dL) & $1.9(1.8-2.2)$ & $1.1(1.0-1.3)$ & $<0.0001$ \\
\hline FT3 $(p g / m L)$ & $4.8(4.2-5.6)$ & $2.9(2.8-3.1)$ & $<0.0001$ \\
\hline \multicolumn{4}{|l|}{ Antibody positivity } \\
\hline Male & $8 / 19(42.1 \%)$ & $0 / 6(0.0 \%)$ & 0.019 \\
\hline TPOAb positive & $6 / 19(31.6 \%)$ & $0 / 6(0.0 \%)$ & 0.050 \\
\hline TgAb positive & $7 / 19(36.8 \%)$ & $0 / 6(0.0 \%)$ & 0.031 \\
\hline Female & $18 / 44(40.9 \%)$ & $7 / 18(38.9 \%)$ & 0.88 \\
\hline TPOAb positive & $14 / 44(31.8 \%)^{\#}$ & $5 / 18(27.8 \%)$ & 0.75 \\
\hline TgAb positive & $17 / 44(38.6 \%)^{\# \#}$ & $7 / 18(38.9 \%)$ & 0.99 \\
\hline \multicolumn{4}{|l|}{ Ultrasound findings } \\
\hline \multicolumn{4}{|l|}{ Thyroid volume (mL) } \\
\hline Male & $31.9(24.6-43.4)$ & $13.3(11.6-19.4)$ & 0.0033 \\
\hline Female & $26.4(18.1-37.2)$ & $14.4(10.2-19.8)$ & 0.0072 \\
\hline Presence of nodules & $24 / 56(42.9 \%)$ & $6 / 21(28.6 \%)$ & 0.25 \\
\hline \multicolumn{4}{|l|}{ Nodule size (mm) } \\
\hline$<5$ & $3 / 56(5.4 \%)$ & $2 / 21(9.5 \%)$ & \\
\hline $5-10$ & $11 / 56(19.6 \%)$ & $3 / 21(14.3 \%)$ & \\
\hline $10-20$ & $5 / 56(8.9 \%)$ & $1 / 21(4.8 \%)$ & \\
\hline$>20$ & $5 / 56(8.9 \%)$ & $0 / 21(0.0 \%)$ & \\
\hline AITD pattern in antibody positive patients & $25 / 26$ & $7 / 7$ & 0.49 \\
\hline
\end{tabular}


Table 5 Sequential thyroid function tests available in RTH $\beta$ patients with and without AITD. Data are presented as median (IQR).

\begin{tabular}{l}
\hline \\
\hline Number \\
Age (years old) \\
Observation period (months) \\
Thyroid function tests inconsistent with RTH $\beta(n(\%))$ \\
Overt hypothyroidism \\
Euthyroidism \\
Subclinical thyrotoxicosis \\
Overt thyrotoxicosis \\
\hline
\end{tabular}

inconsistent with RTH $\beta$ during the observation period (Table 5). Serial changes of data in each individual had been evaluated under the same assay condition. Although its prevalence between RTH $\beta$ patients with and without AITD was not different, overt hypothyroidism (Table 6 and Supplementary Fig. 2) with elevated TSH and low FT4 levels and overt thyrotoxicosis (Table 7 and Supplementary Fig. 3) with low TSH and high FT4 levels were detected only among seven patients with AITD. These patients complained of symptoms associated with fluctuating thyroid function and required treatment. Thyroid function test results consistent with RTH $\beta$ were detected at various time points (Tables 6, 7, and Supplementary Figs 2, 3). Two patients having the $\mathrm{R} 383 \mathrm{H}$ mutation temporarily showed normal thyroid hormone and TSH levels without AITD (Tables 1 and 5). There were no over-represented mutations in the group with data inconsistent with RTH $\beta$ (Table 1).

\section{Discussion}

This study describes the characteristics of 68 Japanese patients with RTH $\beta$ in a single institute specializing in thyroid care. We found that RTH $\beta$ patients, especially men, showed a higher frequency of AITD. More than $20 \%$ of patients with RTH $\beta$ temporarily showed thyroid tests inconsistent with RTH $\beta$ during their follow-up, and patients with AITD and specific mutations of THRB were prone to display such findings.

The presence of thyroid autoimmunity is generally more common in women; however, there was no difference in sex regarding the frequency of AITD in RTH $\beta$ patients in our study. Moreover, the frequency of AITD in male RTH $\beta$ patients was significantly higher compared to unaffected relatives; however, this difference was not found in the female patients (Table 4). This result was consistent with

Table 6 Cases of RTH $\beta$ showing overt hypothyroidism due to chronic thyroiditis. Laboratory data at the start of levothyroxine (LT4) treatment is presented. TPOAB and TgAB was estimated by electrochemiluminescence immunoassay for all cases except Case 4, where hemagluttination assay, MCHA and TGHA was used.

\begin{tabular}{|c|c|c|c|c|c|c|c|}
\hline Case detail/ Case & Gender & TSH $(\mu \mid \mathrm{U} / \mathrm{mL})$ & FT4 (ng/dL) & $\mathbf{F T 3}(\mathrm{pg} / \mathrm{mL})$ & TPOAb $(I U / m L)$ & $\operatorname{TgAb}(I U / m L)$ & $\begin{array}{l}\text { THRB } \\
\text { mutation }\end{array}$ \\
\hline $\begin{array}{l}\text { Initially diagnosed with chronic } \\
\text { thyroiditis. After LT4 replacement, } \\
\text { thyroid function began to show data } \\
\text { consistent with RTH } \beta \text {. Further } \\
\text { evaluation revealed a mutation in } \\
\text { THRB. }\end{array}$ & & & & & & & \\
\hline Case 1 & $\mathrm{~F}$ & $200 *$ & 0.7 & NT & 366.0 & 144.5 & K342I \\
\hline Case 2 & $\mathrm{~F}$ & 97.8 & 0.6 & NT & 509.4 & 316.9 & K342I \\
\hline $\begin{array}{l}\text { Case } 3 \\
\text { Reference range for cases } 1,2 \text { and } 3\end{array}$ & $\mathrm{~F}$ & $\begin{array}{c}130.3 \\
0.3-4.0\end{array}$ & $\begin{array}{c}0.7 \\
0.8-2.1\end{array}$ & $\begin{array}{c}2.4 \\
2.2-5.6\end{array}$ & $\begin{array}{l}19.4 \\
<16.0\end{array}$ & $\begin{array}{l}836.3 \\
<28.0\end{array}$ & A234V \\
\hline $\begin{array}{l}\text { Initial thyroid function showed data } \\
\text { consistent with RTH } \beta \text {. Further } \\
\text { evaluation revealed a mutation in } \\
\text { THRB. During the follow up, TSH level } \\
\text { began to be elevated. }\end{array}$ & & & & & & & \\
\hline $\begin{array}{l}\text { Case } 4 \\
\text { Reference range }\end{array}$ & $\mathrm{F}$ & $\begin{array}{c}72.9 \\
0.3-4.0\end{array}$ & $\begin{array}{c}0.9 \\
0.8-2.1\end{array}$ & $\begin{array}{c}4.2 \\
2.2-5.6\end{array}$ & $\begin{array}{l}1: 1600 \\
<1: 100\end{array}$ & $\begin{array}{l}1: 100 \\
<1: 100\end{array}$ & $\mathrm{R} 438 \mathrm{H}$ \\
\hline $\begin{array}{l}\text { Case } 5 \\
\text { Reference range }\end{array}$ & M & $\begin{array}{c}>100 \\
0.3-4.9\end{array}$ & $\begin{array}{c}0.3 \\
0.7-1.6\end{array}$ & $\begin{array}{l}2.0 \\
1.7-3.7\end{array}$ & $\begin{array}{l}447.5 \\
<16.0\end{array}$ & $\begin{array}{l}247.6 \\
<28.0\end{array}$ & M313T \\
\hline
\end{tabular}

https://eje.bioscientifica.com 
the study of Barkoff et al. (6). In addition, the prevalence of AITD in Japanese patients with RTH $\beta$ in this study (more than $40 \%$ ) was higher compared to previous studies $(\sim 25 \%)(4,6,7)$. Japanese individuals are known to have a higher iodine intake than individuals from other countries (12). Although the relationship between iodine intake and the occurrence of AITD is undetermined, several studies have shown a direct relationship between iodine intake and AITD $(13,14)$. The mechanism of increased AITD in patients with RTH $\beta$ has not been elucidated. Gavin et al. have suggested that chronic TSH stimulation in RTH $\beta$ patients activates intrathyroidal lymphocytes to produce pro-inflammatory cytokines such as TNF- $\alpha$, leading to thyroid cell destruction causing AITD (15); however, this hypothesis remains controversial (6).

To the best of our knowledge, no studies have evaluated the sequential thyroid functions and ultrasound findings of a large number of patients with RTH $\beta$. Although RTH $\beta$ patients are known to exhibit discrepant thyroid test results, $29.5 \%$ of patients in this study temporarily showed data inconsistent with RTH $\beta$. Among these, $88 \%(7 / 8)$ of RTH $\beta$ patients with AITD developed overt hypothyroidism or thyrotoxicosis and required treatment (Tables 1, 5, 6, 7, and Supplementary Figs 2, 3). In this study, four of five members in a family with RTH $\beta$ caused by K432I and concurrent AITD presented with overt thyrotoxicosis or overt hypothyroidism (Tables 1, 6 and 7). In the past, several RTH $\beta$ cases have been reported showing changes in thyroid function due to chronic thyroiditis $(16,17,18)$, Graves' disease (19, 20, 21, 22, 23, 24, 25, 26), and painless thyroiditis $(27,28)$, which required treatment.

In contrast, RTH $\beta$ patients without AITD showed only mild and temporary changes of thyroid function test results atypical of RTH $\beta$ (Tables 1 and 5). Among them, two RTH $\beta$ cases with the R383H mutation and without AITD in this study temporarily showed normal thyroid hormone levels with TSH levels in the normal range. Although R383 is located outside of the three hot spot regions, the R383H mutation has been previously reported to cause a mild form of RTH $\beta$ with small goiter, tachycardia, slightly elevated FT4, and normal TSH level (29). In vitro analysis showed that the R383H mutation had a T3-binding affinity of $70 \%$ that of WT and little dominant negative effect, suggesting the importance of the region for dimerization of the receptor $(29,30)$. Similarly, several other cases of RTH $\beta$ (P247L, E311K, R316C, G385E, and R429W), in addition to R383H, presented occasionally normal thyroid hormone levels (31, 32, 33, 34, 35). Two mutants (P247L and R429W) manifest either mild impairment of T3-binding or a weak dominantnegative effect $(30,31,32)$. Structurally, the E311K mutant
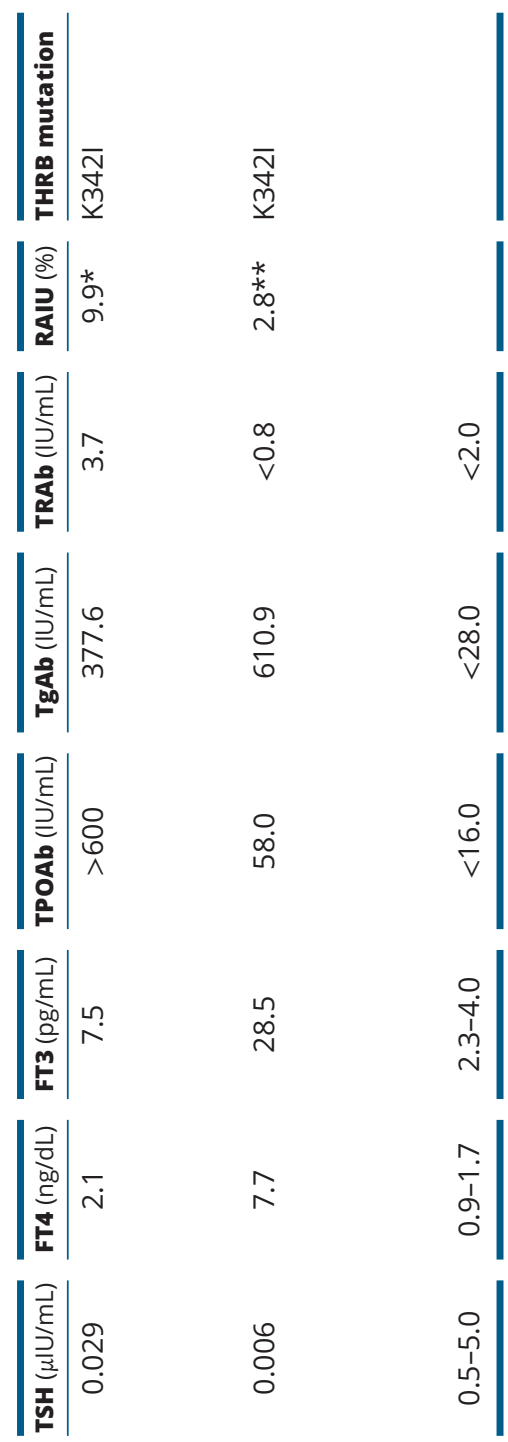

0
$\circ$
0

$$
\text { 垈 }
$$
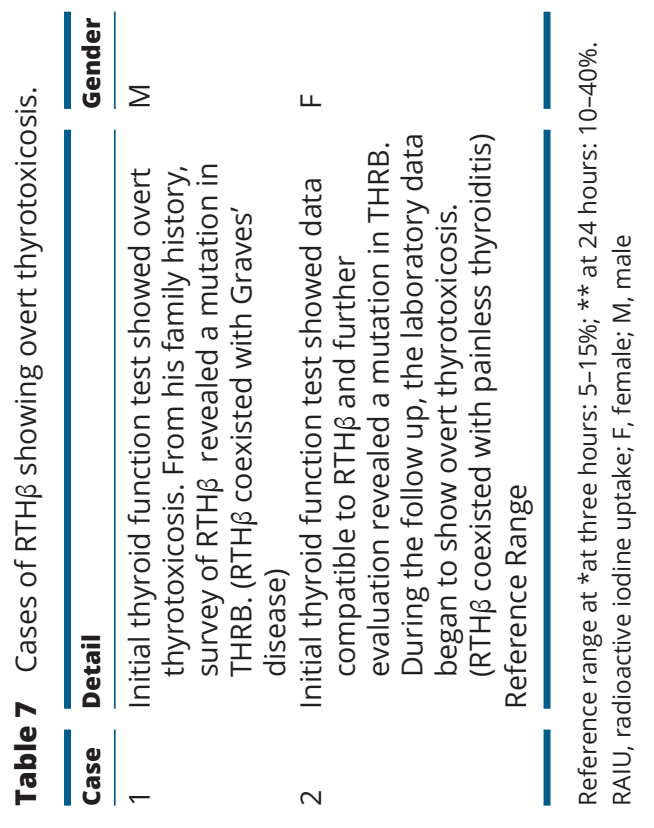
leads to a loss of hydrogen bonds between R383 (33) and the G385E mutant, which is localized adjacent to R383 within the dimerization region (35). Although genotypephenotype correlation in patients with $\mathrm{RTH} \beta$ is still controversial (36), we must be aware of fluctuations in thyroid function among patients with RTH $\beta$ due to both concurrent AITD and mutant receptor properties.

Ultrasound examinations revealed a high frequency of thyroid nodules in RTH $\beta$ patients, but no thyroid cancer. Indeed, only a few cases have been reported to have thyroid cancer concurrent with RTH $\beta(37,38,39)$. On the other hand, a mutant knock-in mouse with a targeted potent dominant negative TR $\beta$ mutant, which is identical in a patient with RTH $\beta$ (40), spontaneously developed thyroid cancer when homozygous, but not when heterozygous (41). Apart from the dominant-negative effect for TR $\beta$ regulation, multiple signaling pathways, including nongenomic mechanisms, are induced by the mutation of the two alleles of the THRB gene, consequently leading to thyroid carcinogenesis $(42,43)$. Both case studies and experimental findings in previous reports indicate that although elevated TSH levels may promote thyroid cell proliferation, patients with a heterozygous THRB mutation have no obvious risk for the development of thyroid cancer.

This study has some limitations. This was a retrospective study with varied follow-up periods and a relatively small number of participants in the unaffected relatives group. The median age at diagnosis among probands was 36.0 years, possibly because our hospital has no department of pediatrics; otherwise, Japanese general practitioners are unaware of RTH $\beta$. In addition, $13.2 \%$ were misdiagnosed to have Graves' disease at initial evaluation; however, all misdiagnoses were corrected to RTH $\beta$ before 2011. The American Thyroid Association guidelines (44) and the diagnostic criteria for RTH $\beta$ published by the Japan Thyroid Association (available at: www.japanthyroid.jp/ en/clinical.html accessed May 23, 2021) have led to an increased awareness of RTH $\beta$ resulting in a decrease in the frequency of its misdiagnosis.

In conclusion, a higher frequency of AITD and thyroid test results fluctuations in RTH $\beta$ patients may obscure the presence of RTH $\beta$ during follow-up. Suspicion of RTH $\beta$ should prompt physicians to consider repeat laboratory tests at different time periods and performing genetic testing to avoid misdiagnosis and inappropriate treatment.

\section{Supplementary materials}

This is linked to the online version of the paper at https://doi.org/10.1530/ EJE-21-0584.
Declaration of interest

The authors declare that there is no conflict of interest that could be perceived as prejudicing the impartiality of this study.

\section{Funding}

This work did not receive any specific grant from any funding agency in the public, commercial, or not-for-profit sector.

\section{Author contribution statement}

$\mathrm{M} \mathrm{O}-\mathrm{H}$ and $\mathrm{E} \mathrm{N}$ designed the study. $\mathrm{M} \mathrm{O}-\mathrm{H}$ extracted the data and performed the statistical analysis. $\mathrm{M} \mathrm{O}-\mathrm{H}$ and $\mathrm{E} \mathrm{N}$ wrote the manuscript. $\mathrm{M}$ $\mathrm{H}$ and $\mathrm{T} \mathrm{K}$ contributed to the patients care and acquisition of data. M I, S F, $\mathrm{M} \mathrm{N}, \mathrm{T} \mathrm{A}$, and A M critically reviewed the article. All authors discussed the results of the study and approved the final manuscript.

\section{Acknowledgements}

The authors are grateful to the staff of Kuma Hospital for their valuable contribution. The authors thank Professor Samuel Refetoff for providing valuable advice after reviewing the manuscript.

\section{References}

1 Refetoff S, DeWind LT \& DeGroot LJ. Familial syndrome combining deaf-mutism, stuppled epiphyses, goiter and abnormally high PBI: possible target organ refractoriness to thyroid hormone. Journal of Clinical Endocrinology and Metabolism 196727 279-294. (https://doi. org/10.1210/jcem-27-2-279)

2 Dumitrescu AM, Korwutthikulrangsri M \& Refetoff S. Impaired sensitivity to thyroid hormone: defects of transport, metabolism, and action. In Werner and Ingbar's the Thyroid a Fundamental and Clinical Text, 11th ed., ch. 66, pp. 868-907. Eds LE Braverman, DS Cooper \& P Kopp. Philadelphia: Wolters Kluwer, 2021.

3 Anselmo J, Cao D, Karriosn T, Weiss RE \& Refetoff S. Fetal loss associated with excess thyroid hormone exposure. JAMA 2004292 691-695. (https://doi.org/10.1001/jama.292.6.691)

4 Vela A, Pérez-Nanclares G, Ríos I, Rica I, Portillo N, Castaño L \& Spanish Group for the Study of RTH. Thyroid hormone resistance from newborns to adults: a Spanish experience. Journal of Endocrinological Investigation 201942 941-949. (https://doi.org/10.1007/s40618-0191007-4)

5 Amor AJ, Halperin I, Alfayate R, Borrás VM, Escribano A, González C, Gutirrez A, Mauri M, Pérez P, Picó A et al. Identification of four novel mutations in the thyroid hormone receptor- $\beta$ gene in 164 Spanish and 2 Greek patients with resistance to thyroid hormone. Hormones 2014 13 74-78. (https://doi.org/10.1007/BF03401322)

6 Barkoff MS, Kocherginsky M, Anselmo J, Weiss RE \& Refetoff S. Autoimmunity in patients with resistance to thyroid hormone. Journal of Clinical Endocrinology and Metabolism 201095 3189-3193. (https:// doi.org/10.1210/jc.2009-2179)

7 Rivolta CM, Olcese MC, Belforte FS, Chiesa A, Gruñeiro-Papendieck L, Iorcansky S, Herzovich V, Cassorla F, Gauna A, GonzalezSarmiento R et al. Genotyping of resistance to thyroid hormone in South American population. Identification of seven novel missense mutations in the human thyroid hormone receptor beta gene. Molecular and Cellular Probes 200923 148-153. (https://doi. org/10.1016/j.mcp.2009.02.002)

8 Kasagi K, Takahashi N, Inoue G, Honda T, Kawachi Y \& Izumi Y. Thyroid function in Japanese adults as assessed by a general health checkup system in relation with thyroid-related antibodies and other clinical parameters. Thyroid 200919 937-944. (https://doi. org/10.1089/thy.2009.0205) 
9 Nishihara E, Nagayama Y, Amino N, Hishinuma A, Takano T, Yoshida H, Kubota S, Fukata S, Kuma K \& Miyauchi A. A novel thyrotropin receptor germline mutation (Asp617Tyr) causing hereditary hyperthyroidism. Endocrine Journal 200754 927-934. (https://doi.org/10.1507/endocrj.k07-088)

10 Yokozawa T, Fukata S, Kuma K, Matsuzuka F, Kobayashi A, Hirai K, Miyauchi A \& Sugawara M. Thyroid cancer detected by ultrasoundguided fine-needle aspiration biopsy. World Journal of Surgery 199620 848-853; discussion 853. (https://doi.org/10.1007/s002689900129)

11 Ito Y, Amino N, Yokozawa T, Ota H, Ohshita M, Murata N, Morita S, Kobayashi K \& Miyauchi A. Ultrasonographic evaluation of thyroid nodules in 900 patients: comparison among ultrasonographic, cytological, and histological findings. Thyroid 2007 17 1269-1276. (https://doi.org/10.1089/thy.2007.0014)

12 Nagataki S. The average of dietary iodine intake due to the ingestion of seaweeds is $1.2 \mathrm{mg} /$ day in Japan. Thyroid 200818 667-668. (https:// doi.org/10.1089/thy.2007.0379)

13 Kahaly GJ, Dienes HP, Beyer J \& Hommel G. Iodide induces thyroid autoimmunity in patients with endemic goitre: a randomised, doubleblind, placebo-controlled trial. European Journal of Endocrinology 1998 139 290-297. (https://doi.org/10.1530/eje.0.1390290)

14 Papanastasiou L, Alevizaki M, Piperingos G, Mantzos E, TseleniBalafouta S \& Koutras DA. The effect of iodine administration on the development of thyroid autoimmunity in patients with nontoxic goiter. Thyroid 200010 493-497. (https://doi.org/10.1089/ thy.2000.10.493)

15 Gavin C, Meggison H \& Ooi TC. Proposing a causal link between thyroid hormone resistance and primary autoimmune hypothyroidism. Medical Hypotheses 200870 1024-1028. (https://doi. org/10.1016/j.mehy.2007.08.015)

16 Fukata S, Brent GA \& Sugawara M. Resistance to thyroid hormone in Hashimoto's thyroiditis. New England Journal of Medicine 2005352 517-518. (https://doi.org/10.1056/NEJM200502033520523)

17 Sato H \& Sakai H. A family showing resistance to thyroid hormone associated with chronic thyroiditis and its clinical features: a case report. Endocrine Journal 200653 421-425. (https://doi.org/10.1507/ endocrj.k05-182)

18 Kammoun I, Bouzid C, Kandara H, Ben Salem L, Turki Z \& Ben Slama C. A case of resistance to thyroid hormone with chronic thyroiditis: discovery of a novel mutation (I54V) Case Reports in Endocrinology 20112011 584930. (https://doi. org/10.1155/2011/584930)

19 Abdellaoui Y, Magkou D, Bakopoulou S, Zaharia R, Raffin-Sanson ML $\&$ Cazabat L. Coexistence of autoimmune hyper- and hypothyroidism in a kindred with reduced sensitivity to thyroid hormone. European Thyroid Journal 20209 263-268. (https://doi.org/10.1159/000506424)

20 González Cabrera N, Kalic AK, Antón Miguel MÁ, Sierra Polo P \& Vicente Vicente MÁ. Hyperthyroidism due to Graves-Basedow disease in a woman refractory to thyroid hormones. Endocrinologia y Nutricion 201259 609-611. (https://doi.org/10.1016/j.endonu.2011.11.014)

21 Ogawa K, Yoshida M, Hayashi Y, Murata Y, Miyata M \& Oiso Y. A rare case of resistance to thyroid hormone coexisting with Graves' disease. Endocrine 201140 318-319. (https://doi.org/10.1007/s12020-011-94910)

22 Ramos-Leví AM, Moreno JC, Álvarez-Escolá C, Lacámara N \& Montañez MC. Coexistence of thyroid hormone resistance syndrome, pituitary adenoma and Graves' disease. Endocrinologia y Nutricion 2016 63 139-141. (https://doi.org/10.1016/j.endonu.2015.12.003)

23 Sato H. Clinical features of primary hyperthyroidism caused by Graves' disease admixed with resistance to thyroid hormone (P453T). Endocrine Journal 201057 687-692. (https://doi.org/10.1507/endocrj. k10e-066)

24 Shiwa T, Oki K, Awaya T, Nakanishi S \& Yamane K. Resistance to thyroid hormone accompanied by Graves' disease. Internal Medicine 201150 1977-1980. (https://doi.org/10.2169/ internalmedicine.50.4904)
25 Sivakumar T \& Chaidarun S. Resistance to thyroid hormone in a patient with coexisting Graves' disease. Thyroid 201020 213-216. (https://doi.org/10.1089/thy.2009.0175)

26 Sun H, Xu S, Xie S, Cao W, Chen G, Di H, Zheng R, Li X, Mao X \& Liu C. Graves' disease coexisting with resistance to thyroid hormone: a rare case. Clinical Case Reports 20186 337-341. (https://doi. org/10.1002/ccr3.1344)

27 Taniyama M, Otsuka F, Tozaki T \& Ban Y. Thyroid profiles in a patient with resistance to thyroid hormone and episodes of thyrotoxicosis, including repeated painless thyroiditis. Thyroid 201323 898-901. (https://doi.org/10.1089/thy.2012.0004)

28 Nagamine T, Noh JY, Emoto N, Kogai T, Hishinuma A, Okajima F \& Sugihara H. Painless destructive thyroiditis in a patient with resistance to thyroid hormone: a case report. Thyroid Research 201912 8. (https:// doi.org/10.1186/s13044-019-0072-2)

29 Clifton-Bligh RJ, de Zegher F, Wagner RL, Collingwood TN, Francois I, Van Helvoirt M, Fletterick RJ \& Chatterjee VK. A novel TR beta mutation $(\mathrm{R} 383 \mathrm{H})$ in resistance to thyroid hormone syndrome predominantly impairs corepressor release and negative transcriptional regulation. Molecular Endocrinology 199812 609-621. (https://doi.org/10.1210/mend.12.5.0113)

30 Hayashi Y, Sunthornthepvarakul T \& Refetoff S. Mutations of CpG dinucleotides located in the triiodothyronine (T3)-binding domain of the thyroid hormone receptor (TR) beta gene that appears to be devoid of natural mutations may not be detected because they are unlikely to produce the clinical phenotype of resistance to thyroid hormone. Journal of Clinical Investigation 199494 607-615. (https:// doi.org/10.1172/JCI117376)

31 Pohlenz J, Manders L, Sadow PM, Kansal PC, Refetoff S \& Weiss RE. A novel point mutation in cluster 3 of the thyroid hormone receptor beta gene (P247L) causing mild resistance to thyroid hormone. Thyroid 1999 9 1195-1203. (https://doi.org/10.1089/thy.1999.9.1195)

32 Catargi B, Monsaingeon M, Bex-Bachellerie V, Ronci-Chaix N, Trouette H, Margotat A, Tabarin A \& Beck-Peccoz P. A novel thyroid hormone receptor-beta mutation, not anticipated to occur in resistance to thyroid hormone, causes variable phenotypes. Hormone Research 200257 137-142. (https://doi.org/10.1159/000057965)

33 Slezak R, Lukienczuk T, Noczynska A, Karpinski P, Lebioda A, Misiak B \& Sasiadek MM. A novel p.E311K mutation of thyroid receptor beta gene in resistance to thyroid hormone syndrome, inherited in autosomal recessive trait. Hormone and Metabolic Research 201244 704-707. (https://doi.org/10.1055/s-0032-1312666)

34 Ueda Y, Tagami T, Tamanaha T, Kakita M, Tanase-Nakao K, Nanba K, Usui T, Naruse M \& Shimatsu A. A family of RTH $\beta$ with p.R316C mutation presenting occasional syndrome of inappropriate secretion of TSH. Endocrine Journal 201562 251-260. (https://doi.org/10.1507/ endocrj.EJ14-0422)

35 Korwutthikulrangsri M, Dosiou C, Dumitrescu AM \& Refetoff S. A novel G385E variant in the cold region of the T3-binding domain of thyroid hormone receptor beta gene and investigations to assess its clinical significance. European Thyroid Journal 20198 293-297. (https:// doi.org/10.1159/000503860)

36 Hayashi Y, Weiss RE, Sarne DH, Yen PM, Sunthornthepvarakul T, Marcocci C, Chin WW \& Refetoff S. Do clinical manifestations of resistance to thyroid hormone correlate with the functional alteration of the corresponding mutant thyroid hormone-beta receptors? Journal of Clinical Endocrinology and Metabolism 199580 3246-3256. (https:// doi.org/10.1210/jcem.80.11.7593433)

37 Kim HK, Kim D, Yoo EH, Lee JI, Jang HW, Tan AH, Hur KY, Kim JH, Kim KW, Chung JH et al. A case of resistance to thyroid hormone with thyroid cancer. Journal of Korean Medical Science 201025 1368-1371. (https://doi.org/10.3346/jkms.2010.25.9.1368)

38 Paragliola RM, Lovicu RM, Locantore P, Senes P, Concolino P, Capoluongo E, Pontecorvi A \& Corsello SM. Differentiated thyroid cancer in two patients with resistance to thyroid hormone. Thyroid 201121 793-797. (https://doi.org/10.1089/thy.2010.0233) 
39 Ramos-Prol A, Antonia Pérez-Lázaro M, Isabel del Olmo-García M, León-de Zayas B, Moreno-Macián F, Navas-de Solis S \& Merino-

Torres JF. Differentiated thyroid carcinoma in a girl with resistance to thyroid hormone management with triiodothyroacetic acid. Journal of Pediatric Endocrinology and Metabolism 201326 133-136. (https://doi. org/10.1515/jpem-2012-0230)

40 Parrilla R, Mixson AJ, McPherson JA, McClaskey JH \& Weintraub BD. Characterization of seven novel mutations of the c-erbA beta gene in unrelated kindreds with generalized thyroid hormone resistance. Evidence for two 'hot spot' regions of the ligand binding domain. Journal of Clinical Investigation 199188 2123-2130. (https://doi. org/10.1172/JCI115542)

41 Suzuki H, Willingham MC \& Cheng SY. Mice with a mutation in the thyroid hormone receptor beta gene spontaneously develop thyroid carcinoma: a mouse model of thyroid carcinogenesis. Thyroid $2002 \mathbf{1 2}$ 963-969. (https://doi.org/10.1089/105072502320908295)

42 Cheng SY. Thyroid hormone receptor mutations and disease: beyond thyroid hormone resistance. Trends in Endocrinology and Metabolism 200516 176-182. (https://doi.org/10.1016/j.tem.2005.03.008)

43 Guigon CJ \& Cheng SY. Novel non-genomic signaling of thyroid hormone receptors in thyroid carcinogenesis. Molecular and Cellular Endocrinology 2009308 63-69. (https://doi.org/10.1016/j. mce.2009.01.007)

44 Ross DS, Burch HB, Cooper DS, Greenlee MC, Laurberg P, Maia AL, Rivkees SA, Samuels M, Sosa JA, Stan MN et al. 2016 American Thyroid Association guidelines for diagnosis and management of hyperthyroidism and other causes of thyrotoxicosis. Thyroid 201626 1343-1421. (https://doi.org/10.1089/thy.2016.0229)

Received 1 June 2021

Revised version received 22 October 2021

Accepted 2 November 2021 